$\xi=-1$

\title{
Spatial Development of Construction: Modeling and its Finan- cial and Investment Support
}

\author{
Olha Komelina $^{1}$, Viktoria Vasiuta ${ }^{2}$, Inna Miniailenko ${ }^{3 *}$

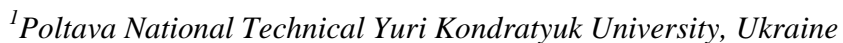 \\ ${ }^{2}$ Poltava National Technical Yuri Kondratyuk University, Ukraine \\ ${ }^{3}$ Poltava National Technical Yuri Kondratyuk University, Ukraine \\ *Corresponding Author E-Mail: Inna.Minyaylenko@Gmail.Com
}

\begin{abstract}
The modern globalization economy requires new approaches to optimizing the spatial format of regional economies. The international experience in developing spatial development strategies of European countries, the USA, China has been researched in this survey. The key components of spatial development, which are based on the economic, social and ecological components of the region's development, are determined in this article. The analysis of literary sources confirmed the significant role of the construction industry in shaping the spatial economy of the state and its regions. The main type of economic activity of the Poltava region economy is construction, the development of which affects other types of economic activities: mining and processing industry, agriculture, transport, etc. The forecast of the construction contribution to the gross regional product of the Poltava region enabled to identify problems and prospects for the construction development. The authors have used the production function in order to model the dependence of the Poltava region's key indicator - the gross regional product from the contribution of each type of economic activity, taking into account the available potential and their investment support. The calculations allowed to determine the growth points of the gross regional product and to construct a model that takes into account the contribution of extractive industry, construction and transport to the development of the region. As a result of redistribution of investment support of the studied industries, the optimal gross regional product was obtained. On the basis of the conducted modeling, a mechanism for regulating financial and investment support for spatial development of construction was developed.
\end{abstract}

Keywords: construction, investment, gross regional product, model, spatial development.

\section{Introduction}

Modern economic development of the regions of Ukraine is characterized by significant changes in the macro-, meso- and microenvironment, represented by the processes of globalization, clusterization, renewal of capital, the introduction of the latest technologies that affect the intensity of its economic growth. Therefore, it is very important to take into account the change in the structure of the regional economy when developingf regional spatial development strategies.

In foreign and domestic economics, there was acquired the actuality of the spatial development theory, which was established in Europe, Canada, and then in the United States of America in the early 70's of the last century. The main provisions of the spatial development theory are related to the work of various scholars of the world (Nora S. Newcombe, K. Desmet, E. Rossi-Hansberg, W. Salet, A. Faludi, etc.).

Along with traditional approaches, there appeared new theoretical concepts of the person's spatial development as its ability to transform and interact with all the elements (psychological aspect) [1], which is important under the conditions of socialization and ecologization of economic development as a whole. However, the theory of spatial development has become the most widespread in the regional economy $[2,3,4]$.

As a rule, the regional space is seen as an effective organization of the territory $[2,3,4]$.
In this context, we can admit an interesting philosophical point of view, where space is considered as the coordination form of a variety of interrelated phenomena, which are arranged respectively to each other, and its individual parts are in certain quantified correlations. The relativity theory in general introduced a new category of "space-time" as the only form of coordination of phenomena, so this definition is an integral part of the notion of development.

The original research by Klaus Desmet and Esteban RossiHansberg in [2] considers spatial development not only as an organization of the territory but it is also considered to be one of the most important compositional economic structures of the research object.

The main components that provide spatial development are: 1) development of the spheres of production and services; 2) the equal weight of these areas; 3 ) investing in new technologies; 4) diffusion of technologies.

The importance of this theory is confirmed by the American postwar experience of breaking the deep economic crisis through the development of construction. Investing in government programs for the construction of new facilities, renovation of the tower allowed to raise the level of employment, its income and ensure the US economy.

Therefore, in the author's research the interrelation of economic activity types, optimal investment provision of priority sectors, in particular, construction and their synergetic effect are expressed in the growth of the gross regional product. 
The transition to sustainable spatial development is a global process in which each country must coordinate with the entire world community to discuss the measures which should be taken in pursuit of the goals and principles of the new civilization model. In the long run, a successful solution to the problem of spatial development will depend on new approaches that will lead to a change in practice at all levels, both in the formal and in private society life.

The spatial development of any country means, in the end, the functioning of its national economic complex, when there are simultaneously provided: satisfaction of growing material and spiritual needs of the population; rational and ecologically safe management and highly efficient use of natural resources; maintenance of natural and ecological living conditions favorable for human health, preservation, reproduction and enhancement of the environment quality and the natural and resource potential of social production.

The modern world points to the growth of the role of space in the regional development. This is due to the consideration of space not only as an integral part of the activity, but also as a complex ecological-socioeconomic system that affects the use of space. It is the heterogeneity of the economic growth of separate European regions and it gave the scientists an idea to study the spatial development of the regions [5].

The generalization of European practices in the management of spatial development [4] enabled to identify the range of basic strategic guidelines for regional planning.

The European Conference of Ministers responsible for Pro-Union / Regional Planning (CEMAT), with the common goal of ensuring sustainable territorial development of the European continent coordinates this activity at the level of 47 member states of the European Council. The main objective of SEMAT is to create and disseminate new ideas and initiatives on regional spatial development issues. Based on the results of advanced research, CEMAT also identifies, studies and compares specific projects of the member countries of the European Council concerning implementation of the policy on sustainable spatial development $[4,6]$.

CEMAT identified the main strategic challenges that will have an impact on spatial development in future, namely:

- demography, migration and their impact on territorial development;

- Territorial impact of the new energy paradigm in Europe (energy supply, energy saving and new geography of power systems);

- influence of globalization processes;

- creation of new transport and trade corridors, access to basic services.

- climate changes, measures aimed at preventing natural disasters in the territorial dimension;

- the role of the spatial development policy to ensure a sustainable human environment and landscape;

- Cross-border cooperation and territorial integration of the European continent.

Spatial development programs are also developed by such European countries as Germany, Slovenia, the Czech Republic, Poland, Greece and others in [6-10], where strategic guidelines for the development of key economic sectors have been formed, as well as measures to ensure socio-eco-oriented production, that is the balanced, sustainable development of countries.

\section{The Statement of Basic Materials}

The urgent need to overcome acute resource-ecological crisis, comprehensive environmental rehabilitation, elimination of the causes of social and ecological catastrophe requires a radical improvement of natural resource use, economical spending of natural resources, and the identification of optimal investments in all sectors of production. From this, the effectiveness of the regional economy, the rate of economic growth and the increase in the living standard of the region's population, as well as the amounts of the GRP and the means for solving socio-economic problems [11] depend to a large extent on the effectiveness of the regional economy.

On the other hand, the regions of Ukraine urgently need reconstruction and modernization of construction objects, outdated and backward technologies taking into account resource-ecological requirements, factors, criteria, quality standards [12] and restrictions. All this should be done on the basis of the use of environmentally safe and energy-efficient technologies, waste-free or low-waste closed production cycles, which enable the complex use of mineral resources and minimize the emission of pollutants into the environment or completely utilize them.

Spatial development strategies are associated with projections of the economic development impact on the environment. [13]. In general, the impact of the environmental situation on the indicators of the economy of cities, regions, countries is a key element in the formation of a strategic plan. Daniel Caparros-Midwood considers the spatial optimization of climate changes, transport risks in [14]. Guoping Huang's research focuses on the peculiarities of developing strategies for the development of the cities of West China, that is, the areas where environmental impact is a compulsory element in [15]. A clear sequence of actions aimed at regulating the environmental quality as an extremely important prelanguage of the transition to the model of spatial economic development depends on a number of factors. Of primary importance among them at the present stage of market transformation in the regions are:

- organization of monitoring of pollution and sources of pollution, determination of pollution levels of all components and resources of the natural environment and identification of the most dangerous places for human health;

- organization of system monitoring of landscapes and agrolandscapes transformation, changes in the state of terrestrial and aquatic ecosystems under the influence of anthropotechnological loading;

- assessment of negative impacts on a man and ecosystem in relation to the maximum permissible and critical levels of pollution and anthropogenic load, as well as the development of criteria for the admissibility and criticality of these impacts on various elements of the biosphere and a man;

- assessment of ecological, economic, social and aesthetic damage to the environment caused by its pollution and degradation;

- forecast of dynamics of antropotechnogenic influences and loads on the biosphere, as well as the assessment of negative consequences that arise in this case;

- substantiation of priority directions of environmental activity and resource-ecological problems solution of socio-economic regional development taking into account the requirements of resource and ecological safety;

- development of effective and ecologically safe technical and technological solutions, optimal, in terms of environmental criteria, placement of enterprises and industries, which will enable to significantly reduce the negative impact on nature;

- definition of directions, methods of restructuring of new industries and upgrading of environmentally hazardous industries and enterprises in the region.

In the short term, the strategic goal of the simple development of Ukrainian regions should be to overcome the economic and structural crisis that has evolved during the transition to a market economy and a democratic community-based society.

To achieve spatial development, as it has already been mentioned, a comprehensive approach is necessary:

- economic stability - the goal is to create a socially and environmentally sound economy, which ensures decent living standards of the population, the competitiveness of products;

- social well-being - the main goal is to increase the average life expectancy of the population, family planning and rationalization of personal consumption, improvement of the medium-high human existence, development of its social activity, provision of equal opportunities in obtaining medical care, social protection of vulnerable groups of the population; 
- ecological safety - the strategic goal of which is to preserve and restore natural ecosystems, stabilize and improve the quality of the environment, reduce emissions of harmful substances, etc. In the long run, the emphasis of spatial development will shift from the economic to the ecological-social and material to the spiritual, moral and informational. This will ensure the formation of a new society, which does not contradict the theory of the noosphere V.I. Vernadsky [11].

Consequently, we can conclude that the mechanism of providing spatial development involves coordinating the process of quantitative and qualitative changes in the space on the basis of developing an appropriate strategic plan as the main tool for its implementation.

The result of spatial development is a new qualitative state of the research object in the form of a certain ratio of elements, which provides a synergistic effect. The optimal combination of the economic, social, environmental, innovative area of the region, their interaction, coordination and balanced interactions is a priority objective of the regional policy of spatial development and state regulation of the Ukrainian economy.

Construction is one of the key types of economic activity, on which the effectiveness of the regional space depends. The importance of this industry is explained by a number of reasons. First, the construction complex creates a large number of work places and consumes the products of many sectors of the national economy. Secondly, the economic effect of this complex development, the essence of which lies in the multiplicative effect of investment funds invested in construction and its technological modernization, deserves attention.

Construction is appropriate to describe the available labor resources, indicators of profitability, the structure of the construction products volume, investments in this industry.

Quite interesting is the research of Kozma G., Marincsák M. Kulcsár B. on the spatial tendencies of the Hungarian construction industry in [16]. The authors emphasize that the basis of the country's economic development is the construction industry. The impact of the crisis phenomena and the implementation of major infrastructure projects related to the construction of motor roads and railways on the trends of all construction sectors was assessed. It was revealed that the growth of the volume of realized construction products, shows the way out of the country's economic crisis.

The confirmation of the construction development importance is the study of spatial planning of state-owned construction in Turkey [17]. The relationship between the priorities of the state economic policy and market development was determined and the level of construction activity was the main factor influencing the formation of the spatial development imperatives. The authors, studying the problems of spatial structure formation, note the crucial role of large-scale housing construction in $[18,19]$. This is especially true of the countries with overpopulation, in particular China, India.

Undoubtedly, implementation of the spatial development strategy in Ukraine requires the development of the construction industry and construction services market. At the same time, such an approach requires an in-depth study of the peculiarities of this industry development, its impact on the development of the region economy, the justification of the spatial construction development and its financial and investment support, which will create a multiplicative effect in the development of regional space.

The authors of the scientific article have selected the type of economic activity: the construction in the Poltava region.

For express analysis, the index of construction products, capital investment in construction, the structure of the volume of realized construction products by types of enterprises, indicators characterizing the financial results of the activity of construction enterprises were calculated and analyzed (Table 1).

An analysis of the performance indicators of construction enterprises testifies to the growth of sales volumes for the period under investigation. The growth of the main indicators of construction indicates the outcome of the economic crisis.
Table 1: Indicators of the activity of construction enterprises in the Potava region for 2010-2016

\begin{tabular}{|c|c|c|c|c|c|}
\hline \multirow{2}{*}{ Indicators } & \multicolumn{5}{|l|}{ Years } \\
\hline & 2010 & 2013 & 2014 & 2015 & 2016 \\
\hline $\begin{array}{l}\text { Profitability of con- } \\
\text { struction operations, } \%\end{array}$ & 3.6 & 3.6 & 7.6 & 6.1 & 5.9 \\
\hline $\begin{array}{l}\text { The share of construc- } \\
\text { tion companies that } \\
\text { made the profit, } \%\end{array}$ & 57.7 & 64.7 & 66.6 & 72.5 & 70.3 \\
\hline $\begin{array}{l}\text { Specific weight of the } \\
\text { volume of sold prod- } \\
\text { ucts of small construc- } \\
\text { tion enterprises in the } \\
\text { total volume of sold } \\
\text { products in the re- } \\
\text { gion, } \%\end{array}$ & 7.1 & 8.2 & 7.3 & 5.5 & 5.1 \\
\hline $\begin{array}{l}\text { The share of employed } \\
\text { workers in small con- } \\
\text { struction enterprises, } \%\end{array}$ & 12.8 & 11.2 & 10.7 & 10.6 & 9.5 \\
\hline $\begin{array}{l}\text { The structure of the } \\
\text { volume of construction } \\
\text { products sold by types } \\
\text { of enterprises, \%: } \\
\text { - medium enterprises; } \\
\text { - small enterprises; } \\
\text { - microentrepreneur- } \\
\text { ship }\end{array}$ & $\begin{array}{l}58.1 \\
41.9 \\
16.2\end{array}$ & $\begin{array}{l}55.4 \\
44.6 \\
10.2\end{array}$ & $\begin{array}{l}56.2 \\
33.3 \\
10.5\end{array}$ & $\begin{array}{l}59.8 \\
40.2 \\
15.3\end{array}$ & $\begin{array}{l}58.3 \\
41.7 \\
16.1\end{array}$ \\
\hline $\begin{array}{l}\text { Construction product } \\
\text { indices, } \%\end{array}$ & 118.4 & 89.3 & 99.9 & 84.6 & 91.5 \\
\hline $\begin{array}{l}\text { Capital investment in } \\
\text { construction, } \\
\text { mln.UAH }\end{array}$ & 570.7 & 998.2 & 572.6 & 973.8 & 1490.3 \\
\hline
\end{tabular}

The source: compiled by the authors for the statistical collection of the Poltava region for 2016

Thus, the profitability of construction operations in 2016 amounted to $5.9 \%$, which is less compared to 2015 by $0.2 \%$. In 2010, this indicator was only $3.6 \%$ (Fig. 1).

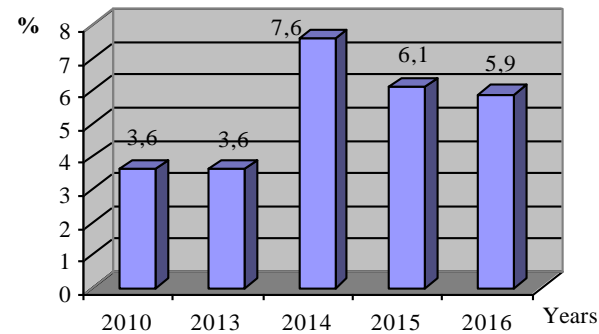

Fig. 1: The profitability dynamics of constructional operational activity of the Poltava region for 2010-2016

It should be noted that in 2016 only $70.3 \%$ of construction enterprises received profits, and in $201042.3 \%$ of construction enterprises were loss-making. It should be noted that the least profitable for construction companies was 2010, although, in general, the profitability of the industry was $3.6 \%$.

The feature of the investigated period is that small and micro enterprises are engaged in construction. This tendency is explained by the feature of taxation of Ukrainian enterprises.

The analysis of the structure of construction enterprises showed that the largest share is occupied by small and micro enterprises. In the structure of the volume of realized construction products, the largest enterprises produce the largest enterprises - 58.3\%, the small ones $-41.7 \%$. The largest number of employed workers works in small enterprises. Although the share of employed workers in small construction companies for the period under study is reduced from $12.8 \%$ in 2010 to $9.5 \%$ in 2016.

Construction enterprises are characterized by a decline in the construction product index from $118.4 \%$ in 2010 to $91.5 \%$ in 2016 (Fig. 2). 


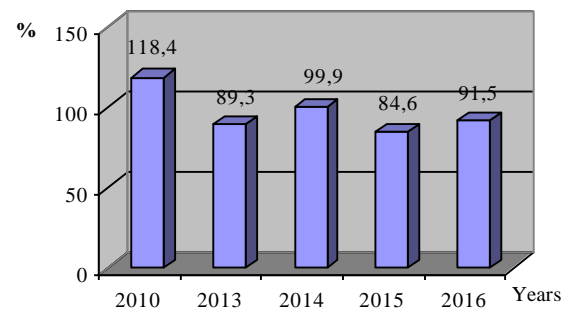

Fig. 2: Construction product indices of the Poltava region for 2010-2016

To determine the price for construction products, it is expedient to use the foreign experience of forming the basket of building components [20]:

The dynamics of capital investment in construction is positive. So in 2016 their amount amounted to 1490.3 million UAH. During the investigated period, investment activity of construction enterprises increased almost 3 times.

Express-analysis of the Poltava region construction is characterized by both positive and negative trends.

The next stage of the study is the forecast of the economic activity type - the construction of the Poltava region. The correlation and regression analysis of the construction contribution in the rudimentary regional product shows a decrease in the investigated indicator. Therefore, it is expedient to predict the spatial development of the construction taking into account the existing interconnections between the key economic activities of the region. The current model can be used to predict, although the correlation coefficient is very low $(\mathrm{r}=0.4)$ and it indicates a low level of communication. Therefore, for the development of construction, it is necessary to study and implement European experience in selecting priority investment projects, attracting public funds, etc. (Fig. 3).

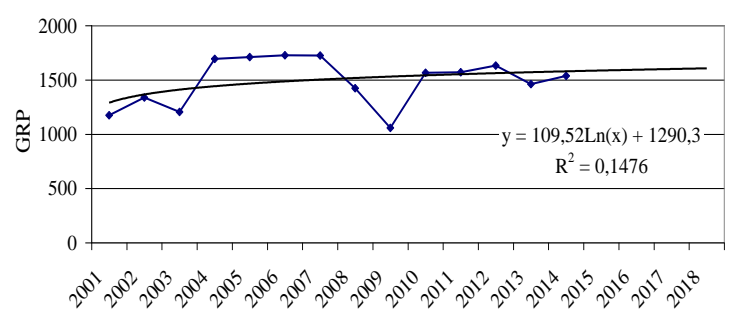

Fig. 3: Trend model construction contribution to the gross regional product (GRP) of the Poltava region for 2001-2018

Therefore, taking into account the analysis of the main indicators of the Poltava region construction, the main problems and obstacles to the development of the priority sector were identified (Fig. 4)

One of the main reasons why many Ukrainian construction companies are now frozen are the harmonization and obtaining of permits, legal, technical, land management and other documentation. In no other area of the economy, this procedure is not so complicated. Construction companies have to be in "close contact" with 20-25 different structural subdivisions of region, city and district law enforcement and control bodies, including authorities and local self-government. The land for the construction of virtually any object, which is frozen at an initial stage, has been acquired at least three years ago. Approximately the same amount of time is required to spend on the development company for all of the above-mentioned approvals. Matters related to the approval of the project budget documentation, the receipt of legal and permissive documents in local authorities may not be resolved for years, although the current law for this is about three to six months.

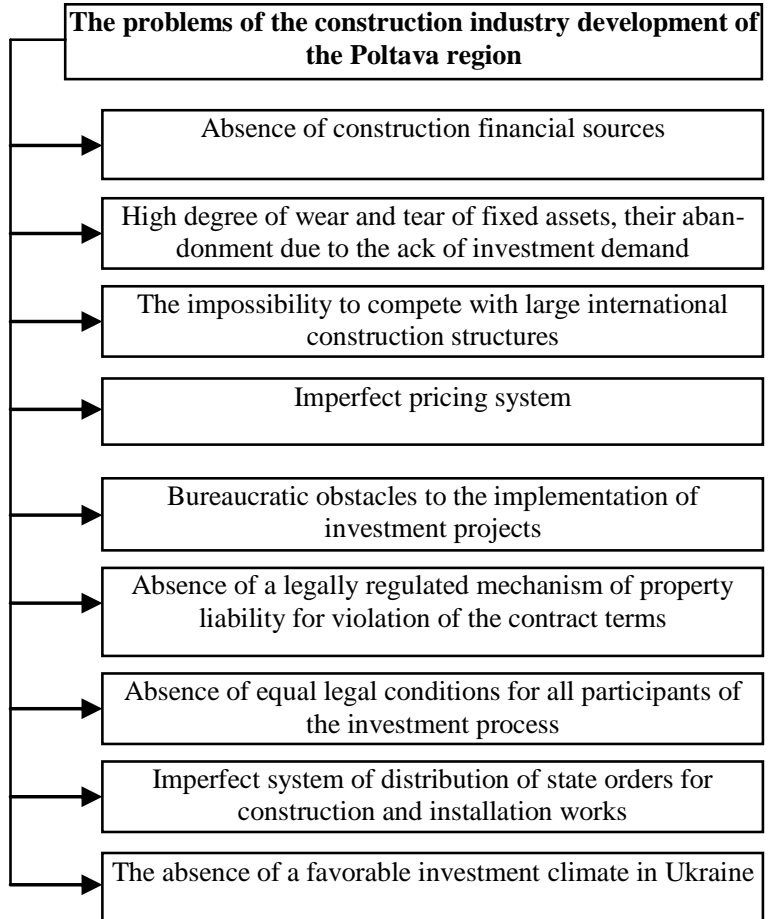

Fig. 4: The problems of the construction industry development of the Poltava region

The problem can be solved only at the legislative level. Without a lengthy process of approval, you can not do it. It is the experience of Poland, where the design organization, which has all the necessary licenses, develops construction project, which initially takes into account all the issues that may arise in the same MES or Sanitary and Epidemiological. Next project falls in the MILITARY body (in Ukraine - a state enterprise "Ukrinvestexpertise"), which checks all the sections and makes a decision about the approved lock or the necesary revision. When the construction starts, the observance of all norms and rules is regularly monitored by another state organization (in Ukraine, State Architectural and Construction Control). In our country there is everything for such a civilized scheme of work. After all, as a result of reduced number of steps it is possible to have control of 20-25 to two or three, and in the construction - from five to two years, as a result the cost of square meters would reduce. And as a result, the volume of construction will increase and additional investments will be attracted. But the primary problem facing the construction industry at this stage is the issue of creating a favorable investment climate in Ukraine, real financial and lending mechanisms to stimulate industrial and housing construction in order to increase the competitiveness of the industry, because market conditions require new bases mutual relations of participants in the investment process in capital construction.

As for the construction industry, in particular in the Poltava region, one can say that the main problem of the development of this industry is the lack of government orders, attention from the regional authorities, the general information field, and the interaction between construction enterprises of the Poltava region. Fluctuations in real estate prices, a decrease in sales of construction products, imbalances in demand and supply, the presence of signs of monopoly and monopolistic competition in the construction market of the Poltava region indicate that market mechanisms do not ensure its comprehensive development. Thus, in the system of management of a building complex it is necessary:

- to expand the powers of local self-government bodies, which should plan their own programs with the use of additional own resources;

- go from cost-based financing to outcome-based financing, which needs an amount of appropriation to achieve the planned results; 
- improve the financial mechanism of the construction complex by introducing new sources and forms of financing at the micro level, using alternative sources of financing.

Therefore, in order to solve the problems of the development of the regional construction complex, it is necessary to intensify investment provision by changing the structure of sources of financing. The Poltava region has sufficient potential for the development of the construction industry, but the process of development and implementation of the strategy for the development of the regional construction complex requires effective mechanisms of interaction between construction companies and other participant in the investment and construction complex. For strategic management of a building complex a model of its functioning in the national economy is required, we have built on a new vision of construction and a new mechanism of relations between business entities (Fig. 5).
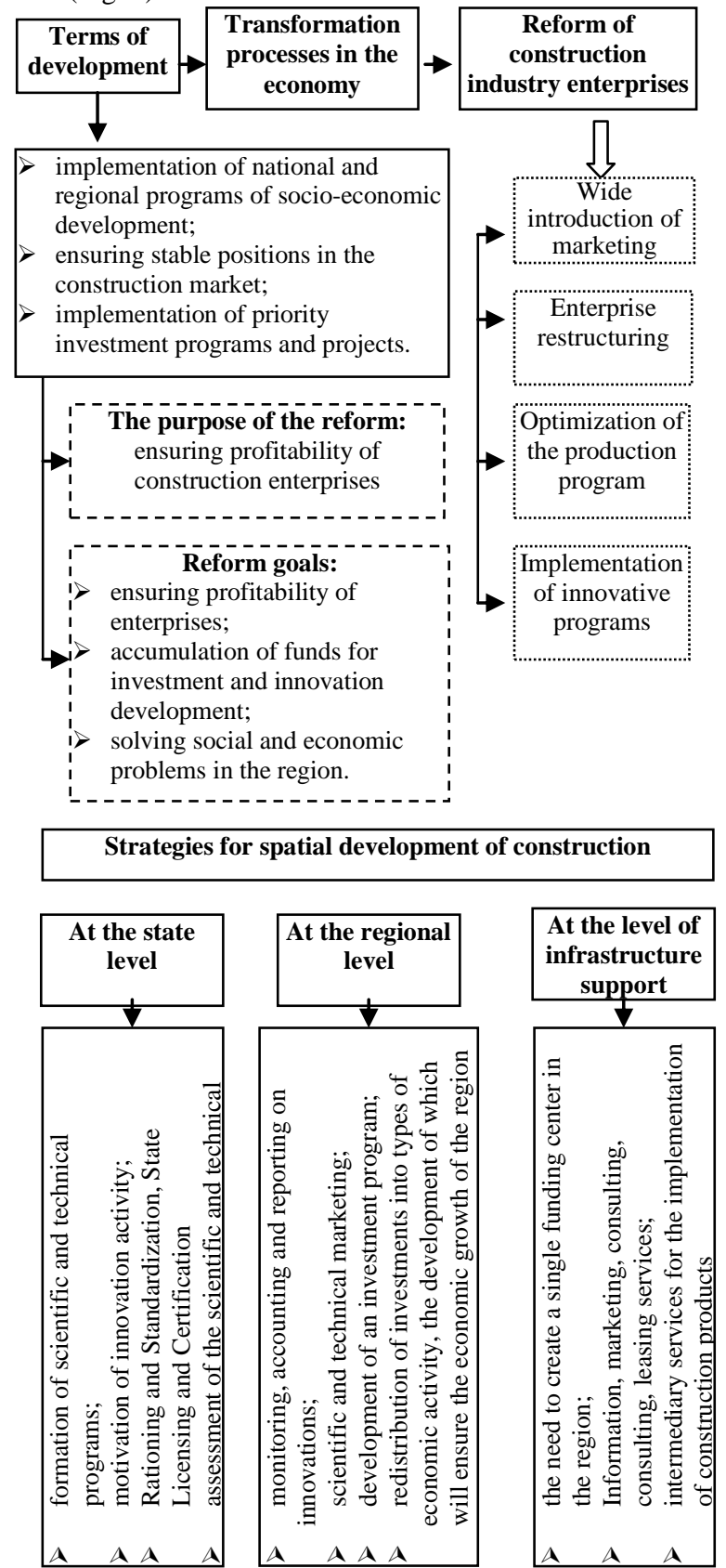

Fig. 5: Features of the development of construction industry enterprises under modern conditions

Regional strategies for spatial development of construction should integrate the economic components of [21], that is, all types of economic activity, in particular mining and processing industry, due to large-scale investment projects for the development of new gas and oil fields; Transport related to regional infrastructure support [18].

The processes of decentralization, which are declared by Ukraine, enable to distribute investments in the economy of certain sectors. The specificity of the construction is that, when implementing large-scale investment projects for new objects, reconstruction and modernization, social needs of local communities [22] must be taken into account and the impact on the ecological situation in the Poltava region should be monitored.

Foreign scientists use a wide range of economical and mathematical methods and models to conduct economic calculations for the determination and evaluation of determinants of spatial development. So, Orenstein, D.E., Frenkel, A., \& Jahshan, F. in [23] developed a methodology for measuring simple-wave development on the basis of the index method.

Curran, D. used the econometric analysis of spatial development in Great Britain, which is based on the sectoral division of the economy in [24]. It is interesting to see the factors that influence the organization of the spatial format and ensure the country's economic growth.

The analysis of the spatial economy of entrepreneurial activity by the authors Tatjana ŠTAUBE1, Ineta GEIPELE in [25] is carried out with the help of regional coefficients of the the Baltic economy characteristics.

The production function that describes the dependence of the GRP on the contribution of the $i, j, k$ type of economic activity is of the following form:

$Y=a_{i j k} X_{i}^{\alpha_{i}} X_{j}^{\alpha_{j}} X_{k}^{\alpha_{k}}$

where $Y$ is GRP;

$\alpha_{i j k}$ is constant;

$\alpha_{i}, \alpha_{j}, \alpha_{k}$ where the coefficients of the model are the $i, j, k$ type of economic activity;

$X_{i}, X_{j}, X_{k}$ is contribution to the $i, j, k$ type of economic activity in the GRP.

Obviously there is the equality:

$$
R_{i} X_{i}+R_{j} X_{j}+R_{k} X_{k}=K_{i}+K_{j}+K_{k}
$$

where $R_{i}, R_{j}, R_{k}$ capital intensity the $i, j, k$ type of economic activity;

$K_{i}, K_{j}, K_{k}$ is investment the $i, j, k$ type of economic activity.

Determined for what values $X_{i}, X_{j}, X_{k}$ reaches the maximum GRP with a constant value of capital in the $i, j, k$ industries.

The model of this task has the form:

$$
\begin{aligned}
& Y=a_{i j k} X_{i}^{\alpha_{i}} X_{j}^{\alpha_{j}} X_{k}^{\alpha_{k}} \rightarrow \max \\
& R_{i} X_{i}+R_{j} X_{j}+R_{k} X_{k}=K_{i}+K_{j}+K_{k}
\end{aligned}
$$

To construct the model, the Lagrange function is used:

$$
\begin{aligned}
& L=a_{i j k} X_{i}^{\alpha_{i}} X_{j}^{\alpha_{j}} X_{k}^{\alpha_{k}}+\lambda\left(R_{i} X_{i}+R_{j} X_{j}+R_{k} X_{k}-\right. \\
& \left.-\left(K_{i}+K_{j}+K_{k}\right)\right) \rightarrow \max
\end{aligned}
$$

Partial derivatives of this function are defined: 


$$
\left\{\begin{array}{l}
\frac{\partial L}{\partial X_{i}}=a_{i j k} \alpha_{i} X_{i}^{\alpha_{i}-1} X_{j}^{\alpha_{j}} X_{k}^{\alpha_{k}}+\lambda R_{i}=0 \\
\frac{\partial L}{\partial X_{j}}=a_{i j k} \alpha_{j} X_{i}^{\alpha_{i}} X_{j}^{\alpha_{j}-1} X_{k}^{\alpha_{k}}+\lambda R_{j}=0 \\
\frac{\partial L}{\partial X_{k}}=a_{i j k} \alpha_{k} X_{i}^{\alpha_{i}} X_{j}^{\alpha_{j}} X_{k}^{\alpha_{k}-1}+\lambda R_{k}=0 \\
R_{i} X_{i}+R_{j} X_{j}+R_{k} X_{k}=K_{i}+K_{j}+K_{k}
\end{array}\right.
$$

The first, second and third equations of the system are determined:

$$
\left\{\begin{array}{c}
a_{i j k} \alpha_{i} X_{i}^{\alpha_{i}-1} X_{j}^{\alpha_{j}} X_{k}^{\alpha_{k}}=-\lambda R_{i} \\
a_{i j k} \alpha_{j} X_{i}^{\alpha_{i}} X_{j}^{\alpha_{j}-1} X_{k}^{\alpha_{k}}=-\lambda R_{j} \\
a_{i j k} \alpha_{k} X_{i}^{\alpha_{i}} X_{j}^{\alpha_{j}} X_{k}^{\alpha_{k}-1}=-\lambda R_{j} \\
R_{i} X_{i}+R_{j} X_{j}+R_{k} X_{k}=K_{i}+K_{j}+K_{k}
\end{array}\right.
$$

The first equation is divided into the second and the third:

$$
\begin{aligned}
\frac{\alpha_{i} X_{j}}{\alpha_{j} X_{i}} & =\frac{R_{i}}{R_{j}} \\
\frac{\alpha_{i} X_{k}}{\alpha_{k} X_{i}} & =\frac{R_{i}}{R_{k}}
\end{aligned}
$$

Thus, the following equation was obtained:

$$
\begin{aligned}
& X_{j}=\frac{R_{i} \alpha_{j}}{R_{j} \alpha_{i}} X_{i} \\
& X_{k}=\frac{R_{i} \alpha_{k}}{R_{k} \alpha_{i}} X_{i} \\
& X_{i}\left(R_{i}+\frac{R_{i} \alpha_{j}}{\alpha_{i}}+\frac{R_{i} \alpha_{k}}{\alpha_{i}}\right)=K_{i}+K_{j}+K_{k} \\
& X_{i}=\frac{\left(K_{i}+K_{j}+K_{k}\right) \alpha_{i}}{R_{i} \alpha_{i}+R_{i} \alpha_{j}+R_{i} \alpha_{k}}=\frac{\left(K_{i}+K_{j}+K_{k}\right) \alpha_{i}}{R_{i}\left(\alpha_{i}+\alpha_{j}+\alpha_{k}\right)} \\
& X_{j}=\frac{\left(K_{i}+K_{j}+K_{k}\right) \alpha_{j}}{R_{j}\left(\alpha_{i}+\alpha_{j}+\alpha_{k}\right)} \\
& X_{k}=\frac{\left(K_{i}+K_{j}+K_{k}\right) \alpha_{k}}{R_{k}\left(\alpha_{i}+\alpha_{j}+\alpha_{k}\right)}
\end{aligned}
$$

The result of the economic-mathematical calculations of the formshaped model, has the following form:

$$
y=0,481717 \times G R P_{\min \text { ing }}^{0.475487} \times G R P_{\text {constr }}^{0.391813} \times G R P_{\text {trans }}^{0.535673}
$$

where $y$ is GRP taking into account the synergistic effect of the contribution of extractive industry, construction and transport; $G R P_{\text {mining }}, G R P_{\text {constr }}, G R P_{\text {trans }}$ is the contribution of extractive industry, construction and transport in the formation of the GRP, respectively.

Realization of the proven model has allowed to determine the optimal investment support of the priority sectors of the Poltava region (Table 2).

An increase in investments in the construction and transport sectors will allow to increase the GRP by 3404.74 million UAH. In the formation conception of the spatial development of Ukraine it was advisable to ignore the development potential and the nucleus of economic growth [26].

Table 2: Optimal investment support for the priority sectors of the Poltava region, UAH mln

\begin{tabular}{|c|c|c|c|c|}
\hline $\begin{array}{c}\text { Type of } \\
\text { economic } \\
\text { activity }\end{array}$ & $\begin{array}{c}\text { Invest- } \\
\text { ments are } \\
\text { actual }\end{array}$ & $\begin{array}{c}\text { Optimal } \\
\text { invest- } \\
\text { ments }\end{array}$ & $\begin{array}{c}\text { Contri- } \\
\text { bution of } \\
\text { industry } \\
\text { in the } \\
\text { GRP }\end{array}$ & $\begin{array}{c}\text { The } \\
\text { advantage of } \\
\text { an optimi- } \\
\text { zation model, } \\
\Delta \mathbf{G R P}\end{array}$ \\
\cline { 1 - 3 } $\begin{array}{c}\text { Mining } \\
\text { industry }\end{array}$ & 3180.765 & 1443.312 & 1177.887 & \multirow{2}{*}{$\mathbf{3 4 0 4 . 7 4}$} \\
\cline { 1 - 3 } Construction & 572.639 & 1189.341 & 606.683 & \\
\hline Transport & 505.281 & 1626.032 & 1369.2 & \\
\hline
\end{tabular}

Source: author's development

According to the sustainable development strategies of Ukraine 2020 and the medium-term plan of priority actions of the Government by 2020, strategies for priority economic activities were formed: construction, extractive industry and transport, the realization of which would ensure a significant increase in the GRP of the Poltava region (Fig. 6).

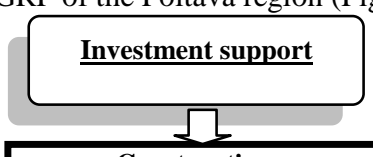

Construction

a) development of new fields of oil and gas;

b) investing in the modernization of construction production through the introduction of a mechanism of public-private partnership [27]; c) improvement of mechanisms for stimulating construction by optimizing its lending for young families and socially vulnerable layers of population;

d) implementation of energy efficient investment projects for new construction and reconstruction, modernization of existing ones.

\section{Mining industry}

a) exploration of new gas and oil fields;

b) extraction of shale gas;

c) an increase in the production of iron ore;

d) inventory of existing oil and gas deposits;

e) technological re-equipment of fixed assets

f) application of environmental technologies for the extraction of crude fossil fuels.

\section{Transport}

a) the development and modernization of the Airport Poltava Airport;

b) creation of a competitive market for transport services;

c) introduction of a mechanism for funding socially important transportation;

d) repair of motorways;

e) reforming the industry by bringing national legislation to EU norms;

f) attracting private investment in the transport sector through the introduction of public private partnership mechanisms

\section{$\Delta \mathrm{GRP}=3404.74 \mathrm{UAH} \mathrm{mln}$}

Fig. 6: Strategies for spatial development of construction, mining industry and transport, author's development

The developed strategy of spatial development of construction, extractive industry and transport will allow not only to increase
Economic and social results

\section{Construction}

the growth of the non-energy-

improvement of the quality of construction products [12];

growth of sales

construction products;

mi projects will allow to

raise the level of employment of

social housing

g) reducing emissions

harmful substances into

environment;

h) improvement of

organization of work [28]

Mining industry

a) Legislative regulation

obtaining licenses for the

developr

b) growth of revenues to the

budget of the region and the

country;

increase of work places;

the underlying funds;

improvement of the ecological

situation in the region.

\section{Transport}

a) creation of conditions for the

development of tourism in the

Poltava region;

b) improving the quality

transport routes;

c) increase in the volume

d) increasing the efficiency

indicators;

e) growth of the social level of

population provision of transpor

services;

reduction of atmospheric

missions. d) reducing the deterioration of 
the GRP of the Poltava region, but also to increase population incomes (Fig. 7), to reduce emissions to the atmosphere (Fig. 8).

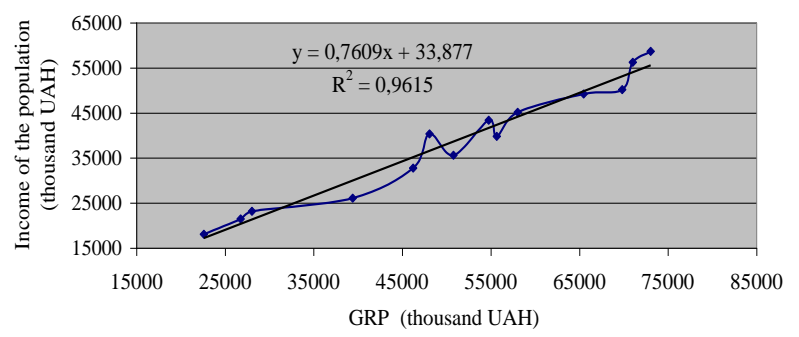

Fig. 7: Impact of GRP growth on population income

It should be noted that the implementation of strategies for spatial development of construction will have an impact on the increase of the population's income of the Poltava region. Confirmation is the calculated level of communication $\mathbf{y}=\mathbf{0 . 7 6 0 9} x+3$ 33.877. The tightness of the income of the population of the Poltava region and the GRP was $\mathbf{0 . 9 8}$, which indicates a high degree of dependence.

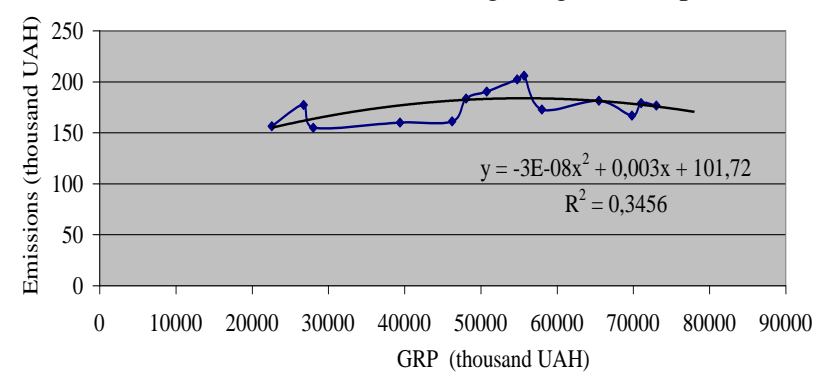

Fig. 8: Effect of GRP growth to replace emissions

A correlation-to-regression analysis was used to determine the impact of GRP growth on the change in atmospheric emissions and household incomes. Thus, the growth of the GRP as a result of realization of the developed spatial strategy will reduce emissions of harmful substances into the atmosphere. Confirmation of dependence is the correlation coefficient $(r=0.6)$, which has an average degree of connection.

\section{Conclusion}

The author's approach to the formation of the spatial construction strategy is based on the creation of a mechanism for scientific substantiation of the priorities of economic development and a broad discussion and implementation of the strategy with participation and public support. But the problem of using this model lies in the fact that a number of branches of the region and the state are characterized by incompleteness of market transformations; the existing legislative and regulatory framework does not contribute to the implementation of a certain strategy; the existing organizational structure of spatial development management needs to be improved. Therefore, in addition to measures to promote the development of basic industries and increase their competitiveness on the domestic and world markets, it is advisable to develop a mechanism for regulation of financial and investment support of spatial development of construction (Fig. 9).

The developed mechanism of financial-investment provision of spatial development of construction should take into account the positions of all stakeholders of society as a whole, carried out in accordance with the principles of scientific validity, consistency, effectiveness of the state policy of regional development and coherence with the budget system.

Realization of the developed model of spatial construction development of the Poltava region will improve its investment and investment climate, provide economic growth of the studied region, and increase the efficiency of using budget expenditures and funds of the state fund of regional development.

\section{STRATEGIC GOALS OF SPACE DEVELOPMENT} CONSTRUCTION

$>$ creation and development of scientific and technical potential of the region;

$>$ introduction of modern ecologically clean, safe. energy and resource-saving technologies of building production;

$>$ introduction of new production quality standards for construction products;

$>$ financial support for the creation of innovative and investment potential of the region.

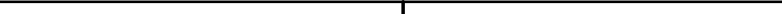

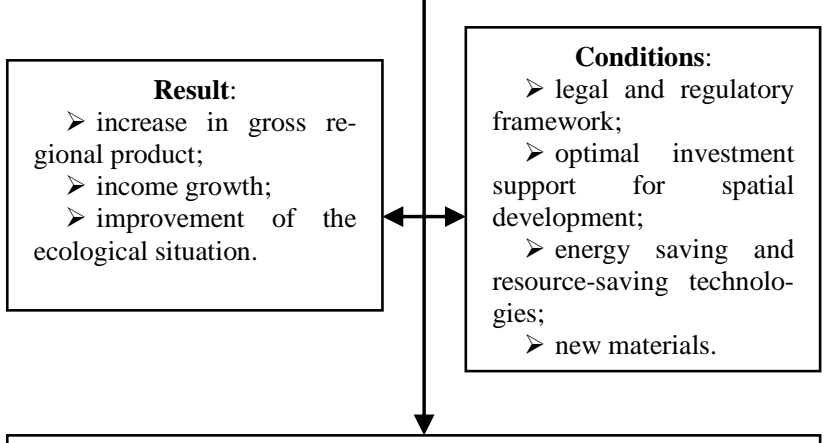

\section{MECHANISM OF REGULATION OF FINANCIAL AND INVESTMENT SUPPORT OF SPATIAL DEVELOPMENT OF CONSTRUCTION}

State regulation

$>$ support of entrepreneurship in the construction sector, state support of the financial and credit sphere for the development of investment activity;

creation of the legislative framework, promotion of investment in new construction, reconstruction, modernization;

$>$ protection of domestic products in the domestic market;

$>$ financial support for the implementation of investment projects;

$>$ promoting the protection of the rights and interests of the subjects of investment activity in construction.

Regulation by the regional administrations

$>$ consideration and approval of regional investment projects credited by the region's credit, the state fund for regional development;

$>$ financing of regional innovative programs through financial and credit institutions (their regional branches) within the limits allocated in these budgets;

control the financing of regional investment projects with the funds of the regional budget.

Fig. 9: Mechanism of regulation of financial and investment support of spatial development of construction, author's development

\section{References}

[1] Nora S. Newcombe, David H. Uttal, \& Megan Sauter (2013), "Spatial Development", The Oxford Handbook of Developmental Psychology, ,Vol. 1: Body and Mind, available online: http://www.oxfordhandbooks.com/view/10.1093/oxfordhb/9780199 958450.001.0001/oxfordhb-9780199958450-e-20

DOI:10.1093/oxfordhb/9780199958450.013.0020

[2] Desmet, Klaus, \& Esteban Rossi-Hansberg (2014), "Spatial Development", American Economic Review, 104 (4): 1211-1243. DOI 10.3386/w15349.

[3] Willem Salet, Johan Woltjer (2009), "New concepts of strategic spatial planning dilemmas in the Dutch Randstad region", International Journal of Public Sector Management, Vol. 22 Issue: 3, pp.235248, available online:https://doi.org/10.1108/09513550910949217

[4] Andreas Faludi (2006), From European spatial development to territorial cohesion policy, Regional Studies, 40:6, 667-678, DOI: 10.1080/00343400600868937

[5] Mehdi Pourpeikari Heris (2017) "Evaluating metropolitan spatial development: a method for identifying settlement types and depicting growth patterns", Regional Studies, Regional Science, 4:1, 7-25, DOI: $10.1080 / 21681376.2016 .1266285$

[6] Spatial Development Strategy of Slovenia, available online: http://www.mop.gov.si/fileadmin/mop.gov.si/pageuploads/podrocja /prostorski_razvoj/SPRS_angleska_verzija.pdf 
[7] National Spatial Development Concept 2030 as an example of coordination tool for public policies, available online: file:///C:/Users/VVV/Downloads/4_PZ_PL_MRD.pdf

[8] National Landscape Strategy (2017-2026), available online: http://www.kormany.hu/download/f/8f/11000/Hungarian\%20Natio nal\%20Landscape\%20Strategy_2017-2026_webre.pdf

[9] Concepts and Strategies for Spatial Development in Germany, available online: https://www.bmvi.de/SharedDocs/DE/Anlage/G/leitbilder-undhandlungsstrategien-raumordnung-en.pdf?_blob=publicationFile

[10] Naude, CM. \& McCoskey, SK. (2000), "Spatial development initiatives and employment creation: will they work?", available online: http://tips.org.za/files/401.pdf

[11] Komelina, O. \& Miniaylenko, I. (2014), "Strategic economic orientations for spatial region development", The Advanced Science, Issue 9, part 2.pp.139-143 DOI: 10.15550/ASG.2014.09.139

[12] Byba, V. \& Ananevych, N. (2014), "The theoretical basis of total quality management products and services" The Advanced Science, Issue 9, part 2, pp.117-122 DOI: 10.15550/ASG.2014.09.117

[13] Nancy Odendaal, Adele McCann (2016), "Spatial planning in the global South: reflections on the Cape Town Spatial Development Framework", International Development Planning Review, Vol.38, Issue: 4, pp. 405-423, DOI: 10.3828/idpr.2016.23

[14] Daniel Caparros-Midwood, Stuart Barr, and Richard Dawson (2017), "Spatial Optimization of Future Urban Development with Regards to Climate Risk and Sustainability Objectives", Risk Analysis, Vol. 37, No. 11, pp.2164-2181, DOI: 10.1111/risa.12777

[15] Guoping Huang (2017) "Modeling Urban Spatial Growth in Mountainous Regions of Western China", Mountain Research and Development, 37(3), pp.367-376, available online: https://doi.org/10.1659/MRD-JOURNAL-D-16-00078.1

[16] Kozma G., Marincsák M., Kulcsár B. (2015), “The transformation of the Hungarian construction industry and spatial tendencies between 2000 and 2012", International Review of Applied Sciences and Engineering, Vol.6, Issue:1, pp. 77-83, available online: https://doi.org/10.1556/1848.2015.6.1.11

[17] Alkay, E., Watkins, C., \& Keskin, B. (2018), "Explaining spatial variation in housing construction activity in Turkey", International Journal of Strategic Property Management, 22(2), 119-130, available online: https://doi.org/10.3846/ijspm.2018.443

[18] Bingsheng Liu, Yuan Chen, Ran Wang, Yinghua Shen, \& Qiping Shen, (2016), "Different interaction mechanisms of market structure in the construction industry TFP from the spatial perspective: A case study in China", KSCE Journal of Civil Engineering, Vol. 20, Issue:1, pp. 23-33 DOI: 10.1007/s12205-015-0444-7

[19] Yuemin Ning \& Zhongmin Yan, (2013), "The Changing industrial and spatial structure in Shangai", Urban Geography, Vol. 16, Issue 7: Chinese Cities and Urbanization II, pp. 577-594, available online: https://doi.org/10.2747/0272-3638.16.7.577

[20] Kenneth D. Walsh, Anil Sawhney, Michelle A. Vachris, (2006) "Improving inter-spatial comparison of construction costs", Engineering, Construction and Architectural Management, Vol.13 Issue:2, pp.123-135, available online: https://doi.org/10.1108/09699980610659599

[21] Alan Townsend, (2009), "Integration of economic and spatial planning across scales", International Journal of Public Sector Management, Vol. 22 Issue: 7, pp.643-659, available online: https://doi.org/10.1108/09513550910993399

[22] John M. Luiz, (2003), "The relevance, practicality and viability of spatial development initiatives: a South African case study", Journal of Theoretical Social Psychology, Vol.23, Issue:5, pp. 433-443, available online: https://doi.org/10.1002/pad.282

[23] Orenstein, D. E., Frenkel, A., \& Jahshan, F. (2014), "Methodology matters: Measuring urban spatial development using alternative methods", Environment and Planning B: Planning and Design, 41, 3-23. DOI: $10.1068 / \mathrm{b} 38017$

[24] Curran, D. (2009). Sectoral Trends and British Regional Economic Growth - A Spatial Econometric Perspective, European Journal of Spatial Development, 37

[25] Tatjana ŠTAUBE1, Ineta GEIPELE, (2017), "Scientific Aspects of Spatial Economic Allocation of Entrepreneurial Activities", Baltic Journal of Real Estate Economics and Construction Management, Vol. 5, Issue:1, available online: https://doi.org/10.1515/bjreecm2017-0007

[26] Melnyk, M., Synyutka, O., \& Kushniretska, O. (2016), "Spatial policy of regional metropolis development in Ukraine: conceptual principles of formation", Economic Annals-XXI, 159(5-6), 43-47, DOI: http://dx.doi.org/10.21003/ea.V159-09

[27] Maruniak, E (2014), "Territorial (spatial) planning: content and evolution of major modern trend", Ukrainian Geographical Journal,
Vol.2, pp. 22-31, available online: https://doi.org/10.15407/ugz2014.02.022

[28] Vasyuta, V.B., Vasyuta, V.V. \& Tron. A. (2015), "Improving the organization of labor in the enterprise", Scientific Journal "ScienceRise”,5/3(10), pp.36-39, available online: http://journals.uran.ua/sciencerise/issue/view/2520 DOI:http://dx.doi.org/10.15587/2313-8416 